\title{
A Critical Discourse Analysis of the Representation of Floyd Protests in Three Electronic Newspapers
}

\section{Mahitab Mohamed Ahmed \\ Ahram Canadian University}

Abstract

The present study aims at exploring in what way transitivity, which is a Critical Discourse Analysis tool, is applied to show the representation of George Floyd protests in three electronic newspapers. The data consists of five online articles from each newspaper published on the official websites of the selected newspapers. Since verbal and material processes are common in any protests, the research focuses on investigating the verbal and material processes in the three electronic newspapers in order to reflect their ideologies. The three newspapers represent different backgrounds. The electronic newspapers are "The Guardian", "Al-Ahram Weekly" and "USA today". The first newspaper is an example of a European newspaper. The second newspaper is an example of a Middle East newspaper. The third one is an example of an American Newspaper. Therefore, the findings of this research show that the three newspapers focus on the verbal processes rather than the material processes.

Keywords: transitivity analysis - material processes - verbal processes electronic newspapers - George Floyd American protests 


\section{تحليل خطاب نقدي لتمثيل احتجاجات فلويد في ثُلاث صحف إلكترونية}

تهدف الدراسة الحالية إلى استكثاف الطريقة التي يتم بها تطبيق التحولات ، وهي أداة لتحليل الخطاب النقدي ، لإظهار تمثيل احتجاجات جورج فلويد في ثلاث صحف إلكترونية. تتكون البيانات من خمسة مقالات على الإنترنت من كل صحيفة منشورة على المواقع الرسمية للصحف المختارة. بما أن العمليات اللفظية و المادية شائعة في أي احتجاجات ، فإن البحث بركز على التحقيق في العمليات اللفظية والمادية في الصحف الإلكترونية الثلاث من أجل عكس أيديولوجياتهم. تمثل الصحف الثناث خلفيات مختلفة. و الصحف الإلكثرونية هي "الجارديان" و "الأهر ام ويكلي" و "يو إس إيه نوداي". الصحيفة الأولى هي مثال لصحيفة أوروبية. الصحيفة الثانية هي مثال لصحيفة الثرق الأوسط. الثالث هو مثال لصحيفة أمريكية. لذلك ، تظهر نتائج هذا البحث أن الصحف الثلاث تركز على العمليات اللفظية بدلاً من العمليات المادية. 


\title{
A Critical Discourse Analysis of the Representation of Floyd Protests in Three Electronic Newspapers
}

\author{
Mahitab Mohamed Ahmed \\ Ahram Canadian University
}

\section{Introduction}

George Floyd protests started as a reaction to the killing of George Floyd, a 46-year-old African American man who died during an arrest after Derek Chauvin, a Minneapolis Police Department officer, knelt on Floyd's neck for nearly nine minutes as three other officers looked on. The George Floyd protests are a progressing arrangement which started in Minneapolis in the United States on May 26, 2020. At the beginning, protests began peacefully as local protests in Minneapolis before quickly spreading worldwide in over 60 countries in support of the Black Lives Matter movement. Afterwards, over 2,000 cities and towns in the United States and around the world watched protests and demonstrations as of June 13, and protests extended for a fourth week after Floyd's death in many cities. Whereas most of the protests were peaceful, demonstrations in some cities descended into riots and widespread robbery, with more being marked by street clashes and police brutality, notably against peaceful protesters and reporters. As a result, a minimum of 200 cities within the U.S. obliged curfews by June 3, whereas at least over 30 states and Washington, D.C, activated over 62,000 National Guard personnel because of the mass unrest. Then, by June 3, a minimum of 11,000 people had been arrested, as well as the four police cops involved in the arrest which led to Floyd's death. Therefore, the protests led to several legislative proposals on federal, state and municipal levels to combat police misconduct, systemic racism, qualified immunity and police brutality in the United States, while the Trump administration drew widespread criticism for its hardline, militarized response and aggressive rhetoric. The protests were conjointly related to the removal and destruction of monuments and statues throughout the country and internationally, such as J. E. B. Stuart Monument in Virginia, the statue of Christopher Columbus at the Minnesota State Capitol, and the Albert Pike Memorial in Washington, D.C.

\subsection{The Aim and Significance of the Study}

Thornborrow says that "[t]he media ... have come to be taken for granted as an integral part of most of people's life" (1999, p.51). Nobody can live without the internet as it spreads like wildfire recently. Moreover, 
one of the advantages of e-papers is that they report news a lot faster than regular newspapers. Therefore, the aim of this study is to examine how the George Floyd protests in the US are represented in foreign electronic newspapers: "The Guardian", "Al Ahram Weekly" and "USA today". The first newspaper is an example of a European newspaper. The second newspaper is an example of a Middle East newspaper. The third one is an example of an American Newspaper. In addition, transitivity analysis tools are applied to show the representation of the recent American protests in these newspapers in order to reflect upon their perspectives.

\subsection{Research Question}

The study aims at answering the following research question:

How does transitivity analysis reflect the representation of George Floyd protests in electronic newspapers?

\section{Theoretical Background}

\subsection{Critical Discourse Analysis Overview}

In the early 1990s, many scholars of CDA started to emerge. Then, they met at the University of Amsterdam to discuss methods and theories of CDA. The scholars are Teun van Dijk, Norman Fairclough, Gunther Kress, Theo Van Leeuwen and Ruth Wodak (Wodak \& Myer, 2001, p.4). As for Fairclough (2013), he believes that CDA has three aspects: relational, dialectical, and transdisciplinary. The relational deals with social relations, rather than communities and individuals, which are complicated because it is "relations between relations", for instance relations between communicative events like conversations and newspapers. It is dialectical as there are dialectical relations between things as they are unlike each other, for example, the relation between power and discourse. In addition, the relationship between the power of people who have authority and the people who do not have authority is rational. Therefore, social processes include several factors which are 'power' and 'discourse'. Moreover, it is an interdisciplinary way of analyzing the text. Fairclough prefers to describe it as a 'transdisciplinary ' which means that the dialogue in the text is considered as a source of theoretical and methodological developments within disciplines and frameworks. He indicates that the main idea of 'texts' is to present themselves to the reader. To establish an entity to a research topic, the researcher leads it to various points like the research questions. As a result, the body of the research is constructed in a transdisciplinary way according to the categories and relations between theories of discourse (pp. 4-5). 
Fairclough (2013) introduces some points that differentiate CDA from other research and analysis. First, it analyses discourse, especially texts. In addition, it analyses relations between discourse and elements of social process on the systematic transdisciplinary analysis level. Secondly, it provides feedback on discourse and includes forms of systematic analysis of texts. Thirdly, it is descriptive as well as normative as it deals with faults in society according to their discursive aspects and tries to find out methods to correct or modify them (pp.10-11).

As for van Dijk, he defines CDA as:

Critical Discourse analysis is a type of discourse analytical research that primarily studies the way social power abuse, dominance and inequality are enacted, reproduced and resisted by text and talk in the social and political context. $(2000$, p.1)

\subsubsection{Discourse and Ideology}

van Dijk (2000) defines ideologies as "... the fundamental beliefs of a group and its members." (p.7). According to several approaches, ideologies are social by their multiple social conditions and functions. On the social level, ideologies reflect beliefs of groups which are gained, used and varied according to different social situations, the interest of the groups and relations between groups in complex societies (van Dijk, 1998, p.135). He asserts "Ours is the Truth, and Their is Ideology" (1998, p.2); thus, it is crucial, on the analytical and theoretical level, to move beyond the common (Sunderlin, 2003, p.16).

Some Critical Discourse analysts agree that certain groups with social power get benefits from ideologies. In addition, events, practices, and behaviors are legitimate and common-sense. Social power belongs to those who have social resources like education, knowledge, and wealth. In contrast to what is mentioned, analysts believe that power and dominance are obtained through different situations not from imposing, from above, on others. For example, if people consider dominance as legitimate, power will be 'jointly produced'. Ideologies present how people or groups interpret the world around them (Mayer, 2008, p.11).

\subsubsection{Discrimination in Discourse}

Racism is both a social practice and an ideology. It is represented through discourse. According to discourse analysts, 'discursive events' include discriminatory linguistic features in its social, political, and historical contexts. In order to criticize and argue against racist opinions, critical discourse analysts should follow two procedures. First, they 
should describe, socio-diagnostically, the anti-racist discursive practices and their efficiency or inefficiency. Second, if they want to engage in political actions and face discrimination, they may participate in civil society and set criticism which defends anti-racist policy (Reisigl \& Wodak, 2001, pp.1-2).

\subsubsection{Transitivity}

Halliday (1994) mentions that there are three major types of process in transitivity: material, mental and relational. Moreover, there are other types which are categorized as processes in transitivity. These processes are categorized as intermediate between the main types. On one hand, in the middle between material and mental there is the behavioral process that presents the inner intentions, consciousness and physiological states. On the other hand, in the middle between mental and rational there is the verbal process which reflects consciousness in language. In addition, in the middle between relational and material there is the existential process which indicates that everything is recognized to be or to exist or to happen (p.107).

\section{Methodology}

\subsection{Data and data Collection}

The main source of the present study is taken from online newspapers. The researcher chose these online newspapers as they represent different backgrounds. The researcher chose "The Guardian" as it is ranked as a leading national newspaper in the UK as indicated in the following figure (Top national newspapers ranked by reach UK 2014 | statistic, 2014). In addition, the researcher chose "USA Today" as it is ranked as from 2014 top media outlets as shown in the following figure (2014 Top Media Outlets, 2014). The articles are selected from a time period between May 2020 and September 2020 to find out the representation of the George Floyd protests in the US in online newspapers of different backgrounds. Accordingly, the data is collected from "The Guardian" which is a British online newspaper, "Al Ahram Weekly" which a Middle East newspaper and "USA Today" which is an American online newspaper. Thus, the data consists of 15 online articles published on "The Guardian", "Al Ahram Weekly" and "USA Today". The study analyzes 5 articles from each newspaper from May 2020 to September 2020. In the present study, the researcher goes through two main procedures. First, the researcher starts by saving the articles from the websites of these newspapers. Then, the researcher applies CDA tool: transitivity. 


\section{Mahitab Mohamed Ahmed}

\section{Analysis}

\subsection{Transitivity Analysis}

The selection of different types of processes and the placement of participants and circumstances reflects the writers' or speakers' inclination, ideology and social and historical context. According to Fairclough (1992), "system of transitivity makes options available, and which process type is chosen to signify a real process may be of cultural, political or ideological significance" (p.180).

Table 1. Verbal Processes in Al-Ahram Weekly

\begin{tabular}{|c|c|c|c|c|}
\hline No. & Sayer & $\begin{array}{l}\text { Verbal } \\
\text { process }\end{array}$ & Verbiage & Source \\
\hline 1 & $\begin{array}{l}\text { many of the } \\
\text { protesters }\end{array}$ & call & "Look in the mirror" & Article 1 \\
\hline 2 & $\begin{array}{l}\text { Marvin Rees } \\
\text { (who is of } \\
\text { African } \\
\text { descent) }\end{array}$ & said & $\begin{array}{l}\text { "I think circumstances } \\
\text { came to a head and } \\
\text { people felt the need to } \\
\text { take the statue down," }\end{array}$ & Article 1 \\
\hline 3 & $\begin{array}{l}\text { Marvin Rees } \\
\text { (who is of } \\
\text { African } \\
\text { descent) }\end{array}$ & said & $\begin{array}{l}\text { "I can't and won't } \\
\text { pretend the statue of a } \\
\text { slave trader in a city I } \\
\text { was born and grew up in } \\
\text { wasn't an affront to me } \\
\text { and people like me." }\end{array}$ & Article 1 \\
\hline 4 & $\begin{array}{l}\text { Marvin Rees } \\
\text { (who is of } \\
\text { African } \\
\text { descent) }\end{array}$ & said & $\begin{array}{l}\text { "People in Bristol who } \\
\text { don't want that statue in } \\
\text { the middle of the city } \\
\text { came together, and it is } \\
\text { my job to unite, hear } \\
\text { those voices, and hold } \\
\text { those truths together for } \\
\text { people for whom that } \\
\text { statue is a personal } \\
\text { affront," }\end{array}$ & Article 1 \\
\hline 5 & $\begin{array}{c}\text { British } \\
\text { historian David } \\
\text { Olusoga }\end{array}$ & said & $\begin{array}{l}\text { "removing statues is not } \\
\text { erasing history. Statues } \\
\text { are not the mechanisms } \\
\text { by which we understand } \\
\text { history. We learn history } \\
\text { through museums, books } \\
\text { and television } \\
\text { programmes," }\end{array}$ & Article 1 \\
\hline 6 & Olusoga & told the BBC & $\begin{array}{l}\text { "Statues are not about } \\
\text { remembering history" }\end{array}$ & Article 1 \\
\hline
\end{tabular}




\begin{tabular}{|c|c|c|c|c|}
\hline No. & Sayer & $\begin{array}{c}\text { Verbal } \\
\text { process }\end{array}$ & Verbiage & Source \\
\hline 7 & The University & said & $\begin{array}{l}\text { that the statue would } \\
\text { stay, with modifications } \\
\text { that "draw attention to } \\
\text { this history [and] do } \\
\text { justice to the complexity } \\
\text { of the debate." }\end{array}$ & Article 1 \\
\hline 8 & $\begin{array}{l}\text { Matt Hancock, } \\
\text { the health } \\
\text { secretary, }\end{array}$ & said & $\begin{array}{l}\text { "I think, thankfully, that } \\
\text { this is all based in } \\
\text { response to events in } \\
\text { America rather than here, } \\
\text { but we also must } \\
\text { continue the drive here } \\
\text { for tolerance and genuine } \\
\text { equality of opportunity," }\end{array}$ & Article 1 \\
\hline 9 & $\begin{array}{c}\text { Matt Hancock, } \\
\text { the health } \\
\text { secretary, }\end{array}$ & said & $\begin{array}{l}\text { "I don't, but I do think } \\
\text { there's injustice that } \\
\text { needs to be tackled, and } \\
\text { I've spent my political } \\
\text { life fighting for } \\
\text { equality." }\end{array}$ & Article 1 \\
\hline 10 & $\begin{array}{l}\text { Dawn Butler (a } \\
\text { former Labour } \\
\text { Party minister } \\
\text { for young } \\
\text { people) }\end{array}$ & said & $\begin{array}{l}\text { suggestions that the } \\
\text { protests largely related to } \\
\text { America were a sign that } \\
\text { the government was } \\
\text { "again not listening and } \\
\text { shows no commitment to } \\
\text { resolving the issues of } \\
\text { racism in our own } \\
\text { country." }\end{array}$ & Article 1 \\
\hline 11 & $\begin{array}{l}\text { Butler (the first } \\
\text { black woman to } \\
\text { speak at the } \\
\text { dispatch box in } \\
\text { the House of } \\
\text { Commons) }\end{array}$ & said & $\begin{array}{l}\text { "people are angry in the } \\
\text { UK for many reasons." }\end{array}$ & Article 1 \\
\hline 12 & Trump & said & $\begin{array}{l}\text { that there are groups } \\
\text { manipulating the } \\
\text { situation, not in solidarity } \\
\text { with Floyd but for } \\
\text { electoral reasons. }\end{array}$ & Article 2 \\
\hline 13 & prominent & stated & "Defense movements for & Article 2 \\
\hline
\end{tabular}




\begin{tabular}{|c|c|c|c|c|}
\hline \multicolumn{5}{|c|}{ Mahitab Mohamed Ahmed } \\
\hline No. & Sayer & $\begin{array}{c}\text { Verbal } \\
\text { process }\end{array}$ & Verbiage & Source \\
\hline & $\begin{array}{c}\text { German thinker } \\
\text { Ulrich Beck }\end{array}$ & & $\begin{array}{l}\text { all of civil society are the } \\
\text { lawyers, creative people } \\
\text { and judges of values and } \\
\text { standards." }\end{array}$ & \\
\hline 14 & $\begin{array}{c}\text { The US } \\
\text { Foreign Policy } \\
\text { magazine }\end{array}$ & said & $\begin{array}{l}\text { a central thread linked } \\
\text { the unrest across the US } \\
\text { with recent upheavals in } \\
\text { the Middle East, being } \\
\text { the basic demands of the } \\
\text { protesters. }\end{array}$ & Article 3 \\
\hline 15 & Yassin Alaa & $\begin{array}{l}\text { told the } \\
\text { French news } \\
\text { agency AFP }\end{array}$ & $\begin{array}{l}\text { "I think what the } \\
\text { Americans are doing is } \\
\text { brave, and they should be } \\
\text { angry, but rioting is not } \\
\text { the solution," }\end{array}$ & Article 3 \\
\hline 16 & $\begin{array}{l}\text { Democrat } \\
\text { House Speaker } \\
\text { Nancy Pelosi }\end{array}$ & said & $\begin{array}{l}\text { "Monuments to men who } \\
\text { advocated cruelty and } \\
\text { barbarism to achieve } \\
\text { such a plainly racist end } \\
\text { are a grotesque affront to } \\
\text { the ideals of democracy } \\
\text { and freedom." }\end{array}$ & Article 4 \\
\hline 17 & $\begin{array}{l}\text { Democrat } \\
\text { House Speaker } \\
\text { Nancy Pelosi }\end{array}$ & added & $\begin{array}{l}\text { that statues of men who } \\
\text { participated in a failed } \\
\text { secession war during the } \\
\text { Civil War must be } \\
\text { removed. }\end{array}$ & Article 4 \\
\hline 18 & Biden & said & $\begin{array}{c}\text { "It was an honour to } \\
\text { compete alongside one of } \\
\text { the most talented groups } \\
\text { of candidates." }\end{array}$ & Article 5 \\
\hline
\end{tabular}

While in all the verbal processes focus the sayers are the politicians, only one verbal process focuses on the protesters as sayer. Using the verbal processes, the writers show how the protesters are viewed from different perspectives.

Table 2. Material Processes in Al-Ahram Weekly

\begin{tabular}{|c|c|c|c|c|c|}
\hline No. & Actor & $\begin{array}{c}\text { Material } \\
\text { process }\end{array}$ & Goal & Circumstance & Source \\
\hline $\mathbf{1}$ & Demonstrators & attached & ropes & $\begin{array}{c}\text { to the statue } \\
\text { before pulling } \\
\text { it down }\end{array}$ & Article 1 \\
\hline $\mathbf{2}$ & Peaceful protests & drew doubt & $\begin{array}{c}\text { over the rule } \\
\text { of law and }\end{array}$ & $\begin{array}{c}\text { in the } \\
\text { beginning }\end{array}$ & Article 2 \\
\hline
\end{tabular}


A Critical Discourse Analysis of the Representation of Floyd Protests in Three Electronic Newspapers

\begin{tabular}{|c|c|c|c|c|c|}
\hline No. & Actor & $\begin{array}{l}\text { Material } \\
\text { process }\end{array}$ & Goal & Circumstance & Source \\
\hline & & & $\begin{array}{l}\text { respect for } \\
\text { due process }\end{array}$ & & \\
\hline 3 & $\begin{array}{l}\text { some of the } \\
\text { protesters }\end{array}$ & still camping & out & $\begin{array}{l}\text { in Baghdad's } \\
\text { Tahrir Square }\end{array}$ & Article 3 \\
\hline 4 & $\ldots . . . . .$. & have been met & $\begin{array}{l}\text { the } \\
\text { protesters }\end{array}$ & $\begin{array}{c}\text { with the } \\
\text { violence in US } \\
\text { cities }\end{array}$ & Article 3 \\
\hline 5 & protests & have engulfed & cities & $\begin{array}{l}\text { in Algeria, } \\
\text { Iraq, Lebanon } \\
\text { and Sudan }\end{array}$ & Article 3 \\
\hline 6 & the US protests & had brought & $\begin{array}{l}\text { a similarity } \\
\text { with the } \\
2011 \text { Arab } \\
\text { uprisings }\end{array}$ & $\begin{array}{l}\text { to the minds } \\
\text { of many } \\
\text { Americans } \\
\text { and people } \\
\text { around the } \\
\text { world }\end{array}$ & Article 3 \\
\hline 7 & protests & have spread & $\begin{array}{l}\text { over US } \\
\text { police } \\
\text { racism and } \\
\text { racial } \\
\text { inequality } \\
\end{array}$ & $\begin{array}{l}\text { to more than } \\
140 \text { American } \\
\text { cities in the } \\
\text { days since the } \\
\text { death of Floyd }\end{array}$ & Article 3 \\
\hline 8 & the US protests & will be & $\begin{array}{l}\text { a catalyst for } \\
\text { change }\end{array}$ & at home & Article 3 \\
\hline 9 & these protests & do not threaten & $\begin{array}{l}\text { the safety of } \\
\text { Americans }\end{array}$ & in a pandemic & Article 4 \\
\hline 10 & $\begin{array}{l}\text { angry protesters } \\
\text { and activists }\end{array}$ & demand & $\begin{array}{l}\text { autonomy } \\
\text { for their } \\
\text { cities or } \\
\text { states }\end{array}$ & $\begin{array}{l}\text { on social } \\
\text { media }\end{array}$ & Article 4 \\
\hline 11 & $\begin{array}{l}\text { Seattle } \\
\text { protesters }\end{array}$ & made & the demand & $\begin{array}{l}\text { recently in } \\
\text { protest over } \\
\text { the murder of } \\
\text { George Floyd } \\
\text { last month }\end{array}$ & Article 4 \\
\hline 12 & $\begin{array}{l}\text { anti-racism } \\
\text { protests }\end{array}$ & $\begin{array}{c}\text { are } \\
\text { embarrassing }\end{array}$ & & for him & Article 5 \\
\hline
\end{tabular}

In the previous table, the material processes show that the protesters are engaged as actors who are involved and responsible for their own doings. Therefore, the protesters are the actors of all the previous material processes. The verbs in these material processes show how the protesters are effective. In Example 4, protestors are the goals who are affected by this negative process. Thus, in this specific example the writer chooses to hide the actor of the action. 
Mahitab Mohamed Ahmed

Table 3. Verbal Processes in The Guardian

\begin{tabular}{|c|c|c|c|c|}
\hline No. & Sayer & $\begin{array}{c}\text { Verbal } \\
\text { process }\end{array}$ & Verbiage & Source \\
\hline 1 & $\begin{array}{l}\text { Martin Luther } \\
\text { King }\end{array}$ & stated & $\begin{array}{c}\text { A riot is the language of } \\
\text { the unheard. And what is } \\
\text { it that America has failed } \\
\text { to hear? }\end{array}$ & Article 2 \\
\hline 2 & Mayor Jacob Frey & told & $\begin{array}{l}\text { "I do not support the full } \\
\text { abolition of the police } \\
\text { department," }\end{array}$ & Article 3 \\
\hline 3 & protesters & responded & $\begin{array}{c}\text { "Go home, Jacob, go } \\
\text { home" }\end{array}$ & Article 3 \\
\hline 4 & Demonstrators & chanted & "get off our necks" & Article 3 \\
\hline 5 & $\begin{array}{c}\text { Jacquelyn Martell } \\
\text { (one of the protest } \\
\text { organizers) }\end{array}$ & said & $\begin{array}{l}\text { "Harlem is extremely } \\
\text { significant when it comes } \\
\text { to talking about the } \\
\text { disproportionate impact } \\
\text { on black and brown } \\
\text { communities of so many } \\
\text { things - for example, } \\
\text { Covid-19 and police } \\
\text { surveillance," }\end{array}$ & Article 3 \\
\hline 6 & $\begin{array}{l}\text { the fifth-year } \\
\text { safety Justin } \\
\text { Simmons } \\
\end{array}$ & told & $\begin{array}{c}\text { "Your voice is heavy, and } \\
\text { it matters," }\end{array}$ & Article 3 \\
\hline 7 & $\begin{array}{c}\text { the Portland } \\
\text { mayor, Ted } \\
\text { Wheeler }\end{array}$ & said & $\begin{array}{l}\text { "Our community has } \\
\text { serious concerns about the } \\
\text { use of CS gas for crowd } \\
\text { management, particularly } \\
\text { during a time when we're } \\
\text { battling a pandemic," }\end{array}$ & Article 3 \\
\hline 8 & Demonstrators & chanted & "no justice, no peace" & Article 3 \\
\hline 9 & prosecutors & said & $\begin{array}{c}\text { Two officers in Buffalo, } \\
\text { Robert McCabe and } \\
\text { Aaron Torgalski, were } \\
\text { charged with assault on } \\
\text { Saturday } \\
\end{array}$ & Article 3 \\
\hline 10 & $\begin{array}{c}\text { US } \\
\text { congresswoman } \\
\text { Ilhan Omar } \\
\end{array}$ & told & $\begin{array}{l}\text { "The Minneapolis police } \\
\text { department is rotten to the } \\
\text { root," }\end{array}$ & Article 3 \\
\hline 11 & Trump & said & $\begin{array}{l}\text { "Big crowd, } \\
\text { professionally organized, } \\
\text { but nobody came close to } \\
\text { breaching the fence. If } \\
\text { they had they would have } \\
\text { been greeted with the } \\
\text { most vicious dogs, and } \\
\text { most ominous weapons, I }\end{array}$ & Article 4 \\
\hline
\end{tabular}


A Critical Discourse Analysis of the Representation of Floyd Protests in Three Electronic Newspapers

\begin{tabular}{|c|c|c|c|c|}
\hline No. & Sayer & $\begin{array}{l}\text { Verbal } \\
\text { process }\end{array}$ & Verbiage & Source \\
\hline & & & have ever seen," & \\
\hline 12 & Ted Wheeler & said & $\begin{array}{l}\text { citizens must stay home } \\
\text { between } 8 \mathrm{pm} \text { and } 6 \mathrm{am}, \\
\text { starting immediately. }\end{array}$ & Article 4 \\
\hline 13 & $\begin{array}{l}\text { Governor Tim } \\
\text { Walz }\end{array}$ & told & $\begin{array}{l}\text { "Quite candidly, right } \\
\text { now, we do not have the } \\
\text { numbers," }\end{array}$ & Article 4 \\
\hline 14 & $\begin{array}{l}\text { the city police } \\
\text { chief, Medaria } \\
\text { Arradondo } \\
\end{array}$ & said & $\begin{array}{l}\text { "We will not have another } \\
\text { repeat of what happened } \\
\text { at the third precinct," }\end{array}$ & Article 4 \\
\hline 15 & Sergio Pineda & said & $\begin{array}{l}\text { "It's all Latino businesses } \\
\text { around here. I don't } \\
\text { support what the cops did, } \\
\text { but I don't support what's } \\
\text { going on," }\end{array}$ & Article 4 \\
\hline 16 & $\begin{array}{l}\text { Erika Shields, } \\
\text { Atlanta's police } \\
\text { chief }\end{array}$ & said & $\begin{array}{l}\text { Protesters were } \\
\text { "understandably upset" } \\
\text { and that the country faces } \\
\text { a "recurring narrative" of } \\
\text { black men being killed. }\end{array}$ & Article 4 \\
\hline 17 & $\begin{array}{c}\text { Gwen Carr, } \\
\text { Garner's mother }\end{array}$ & said & $\begin{array}{l}\text { "They have to stop } \\
\text { coming into our } \\
\text { neighbourhoods and } \\
\text { brutalising, terrorising, } \\
\text { murdering," }\end{array}$ & Article 4 \\
\hline 18 & $\begin{array}{l}\text { Hundreds of } \\
\text { protesters }\end{array}$ & chanting & $\begin{array}{l}\text { "Fuck the police," and } \\
\text { "No justice, no peace." }\end{array}$ & Article 4 \\
\hline 19 & $\begin{array}{l}\text { Kimberly Sue, a } \\
\text { physician }\end{array}$ & said & $\begin{array}{l}\text { "Police violence is one of } \\
\text { the biggest health issues in } \\
\text { our country," }\end{array}$ & Article 4 \\
\hline 20 & 1,600 protesters & chanting & "Throw him out" & Article 5 \\
\hline 21 & demonstrators & shouted & $\begin{array}{l}\text { "Get off our necks" and } \\
\text { "Racism is America's } \\
\text { original sin" }\end{array}$ & Article 5 \\
\hline 22 & Obama & said & $\begin{array}{l}\text { "As scary and uncertain } \\
\text { these times may be, they } \\
\text { are also a wake-up call. } \\
\text { And they're an incredible } \\
\text { opportunity for your } \\
\text { generation," }\end{array}$ & Article 5 \\
\hline 23 & $\begin{array}{l}\text { The Minneapolis } \\
\text { city council } \\
\text { president, Lisa } \\
\text { Bender, }\end{array}$ & said & $\begin{array}{l}\text { "In Minneapolis and in } \\
\text { cities across the United } \\
\text { States, it is clear that our } \\
\text { system of policing is not } \\
\text { keeping our communities } \\
\text { safe," }\end{array}$ & Article 5 \\
\hline
\end{tabular}




\begin{tabular}{|c|c|c|c|c|}
\hline \multicolumn{5}{|c|}{ Mahitab Mohamed Ahmed } \\
\hline No. & Sayer & $\begin{array}{c}\text { Verbal } \\
\text { process }\end{array}$ & Verbiage & Source \\
\hline 24 & $\begin{array}{c}\text { Colin Powell, a } \\
\text { key ally of the } \\
\text { most recent } \\
\text { Republican } \\
\text { president George } \\
\text { W Bush }\end{array}$ & told & $\begin{array}{c}\text { Trump had "drifted away } \\
\text { from the US constitution" }\end{array}$ & Article 5 \\
\hline $\mathbf{2 5}$ & $\begin{array}{c}\text { Cory Booker, the } \\
\text { Democratic } \\
\text { senator and } \\
\text { former } \\
\text { presidential } \\
\text { candidate }\end{array}$ & told & $\begin{array}{c}\text { "we are over-policed as a } \\
\text { society" }\end{array}$ & Article 5 \\
\hline $\mathbf{2 6}$ & $\begin{array}{c}\text { the attorney } \\
\text { general, Bill Barr }\end{array}$ & said & $\begin{array}{c}\text { "I think there's racism in } \\
\text { the United States still but I } \\
\text { don't think that the law } \\
\text { enforcement system is } \\
\text { systemically racist," }\end{array}$ & Article 5 \\
\hline
\end{tabular}

(i) The Guardian adapted 26 verbal processes in 5 articles. Only 7 of them represent the protesters' "chanting" and "shouting". However, the rest of the verbal processes reflect the point of views of the politicians and citizens about the protests and the protesters.

(ii)

(iii) Table 4. Material processes in The Guardian

\begin{tabular}{|c|c|c|c|c|c|}
\hline No. & Actor & $\begin{array}{l}\text { Material } \\
\text { process }\end{array}$ & Goal & Circumstance & Source \\
\hline 1 & protests & $\begin{array}{c}\text { are still } \\
\text { continuing }\end{array}$ & & $\begin{array}{c}\text { after three } \\
\text { heady weeks of } \\
\text { black lives } \\
\text { mattering }\end{array}$ & Article 1 \\
\hline 2 & The uprising & crossed & $\begin{array}{c}\text { borders and } \\
\text { language } \\
\text { barriers }\end{array}$ & & Article 1 \\
\hline 3 & protests & spread & & $\begin{array}{l}\text { throughout the } \\
\text { country }\end{array}$ & Article 2 \\
\hline 4 & demonstrators & painted & $\begin{array}{c}\text { an additional } \\
\text { message }\end{array}$ & on the streets & Article 3 \\
\hline 5 & $\begin{array}{l}\text { Thousands of } \\
\text { demonstrators }\end{array}$ & flooded on & $\begin{array}{c}\text { to San } \\
\text { Francisco's } \\
\text { Golden Gate } \\
\text { Bridge }\end{array}$ & $\begin{array}{l}\text { with the } \\
\text { acquiescence } \\
\text { of authorities }\end{array}$ & Article 3 \\
\hline 6 & Protesters & threw & $\begin{array}{l}\text { bricks and } \\
\text { bottles }\end{array}$ & & Article 4 \\
\hline
\end{tabular}


A Critical Discourse Analysis of the Representation of Floyd Protests in Three Electronic Newspapers

\begin{tabular}{|c|c|c|c|c|c|}
\hline No. & Actor & $\begin{array}{c}\text { Material } \\
\text { process }\end{array}$ & Goal & Circumstance & Source \\
\hline 7 & protesters & blocked & highways & & Article 4 \\
\hline 8 & Protesters & used & barricades & $\begin{array}{c}\text { to break police } \\
\text { vehicle } \\
\text { windshields }\end{array}$ & Article 4 \\
\hline 9 & $\begin{array}{l}\text { Hundreds of the } \\
\text { protesters }\end{array}$ & confronted & police & $\begin{array}{l}\text { outside CNN } \\
\text { headquarters }\end{array}$ & Article 4 \\
\hline 10 & protesters & destroyed & $\begin{array}{c}\text { police } \\
\text { vehicles }\end{array}$ & & Article 4 \\
\hline 11 & $\begin{array}{l}\text { Hundreds of } \\
\text { protesters }\end{array}$ & gathered & $\begin{array}{l}\text { at Barclays } \\
\text { Center in } \\
\text { Brooklyn }\end{array}$ & $\begin{array}{l}\text { on Friday } \\
\text { evening }\end{array}$ & Article 4 \\
\hline 12 & $\begin{array}{c}\text { George Floyd } \\
\text { protests }\end{array}$ & enter & third week & & Article 5 \\
\hline 13 & protests & appeared & $\begin{array}{c}\text { to reflect a } \\
\text { shifting } \\
\text { mood }\end{array}$ & $\begin{array}{l}\text { across the } \\
\text { country }\end{array}$ & Article 5 \\
\hline 14 & $\begin{array}{c}\text { Thousands of } \\
\text { marchers }\end{array}$ & gathered & $\begin{array}{l}\text { close to the } \\
\text { White House }\end{array}$ & $\begin{array}{c}\text { on Sunday } \\
\text { afternoon }\end{array}$ & Article 5 \\
\hline 15 & protesters & stopped & & $\begin{array}{c}\text { outside Trump } \\
\text { International } \\
\text { Hotel in } \\
\text { Manhattan } \\
\end{array}$ & Article 5 \\
\hline 16 & $\begin{array}{l}\text { protests and } \\
\text { rallies }\end{array}$ & spread & $\begin{array}{c}\text { to numerous } \\
\text { smaller } \\
\text { towns }\end{array}$ & in the US & Article 5 \\
\hline 17 & $\begin{array}{l}\text { dozens of } \\
\text { protesters }\end{array}$ & rallied & $\begin{array}{c}\text { carrying } \\
\text { Black Lives } \\
\text { Matter } \\
\text { placards }\end{array}$ & & Article 5 \\
\hline 18 & sizable protests & passed largely & & in cities & Article 5 \\
\hline 19 & protesters & toppled & a statue & & Article 5 \\
\hline
\end{tabular}

According to table 4, the material processes show the protesters as the actors of all the actions of the above mentioned material processes. Verbs like "blocked", "confronted" and "destroyed" give the reader a negative impression about the protesters. In other words, they are used to show a negative representation of the protesters who are the doers of these actions. 
Mahitab Mohamed Ahmed

Table 5. Verbal Processes in USA Today

\begin{tabular}{|c|c|c|c|c|}
\hline No. & Sayer & $\begin{array}{l}\text { Verbal } \\
\text { process }\end{array}$ & Verbiage & Source \\
\hline 1 & Hillary Clinton & told & what they needed to hear & Article 1 \\
\hline 2 & $\begin{array}{l}\text { The majority of } \\
\text { Democrats }\end{array}$ & say & $\begin{array}{l}\text { their top concern is } \\
\text { COVID-19 }\end{array}$ & Article 2 \\
\hline 3 & $\begin{array}{l}\text { almost two in } \\
\text { three }(63 \%) \\
\text { Americans }\end{array}$ & say & $\begin{array}{c}\text { they believe assaults } \\
\text { on police officers have } \\
\text { gotten worse in the past six } \\
\text { months }\end{array}$ & Article 2 \\
\hline 4 & $\begin{array}{l}\text { more than } \\
\text { the } 49 \%\end{array}$ & say & $\begin{array}{l}\text { assaults by police officers } \\
\text { has gotten worse }\end{array}$ & Article 2 \\
\hline 5 & $\begin{array}{c}\text { Cornelia } \\
\text { Cheatham, of } \\
\text { Kyle, Texas }\end{array}$ & says & $\begin{array}{l}\text { she doesn't feel safe in } \\
\text { Trump's America }\end{array}$ & Article 2 \\
\hline 6 & $\begin{array}{l}\text { Dawn Tuller, } \\
\text { 42, of Hebron, } \\
\text { Nebraska }\end{array}$ & says & $\begin{array}{l}\text { that although she doesn't } \\
\text { know exactly what the } \\
\text { president has done to } \\
\text { address the protests, she } \\
\text { agrees with his messaging }\end{array}$ & Article 2 \\
\hline 7 & $\begin{array}{l}\text { Six in } 10 \\
\text { Americans }\end{array}$ & say & $\begin{array}{l}\text { the mainstream media has } \\
\text { made the protests more } \\
\text { dangerous }\end{array}$ & Article 2 \\
\hline 8 & $\begin{array}{l}\text { A majority of } \\
\text { Americans }\end{array}$ & say & $\begin{array}{c}\text { antifa }(53 \%) \text {, conservative } \\
\text { militias }(52 \%) \\
\text { and conservative media } \\
\text { (51\%) contribute to protests } \\
\text { becoming more dangerous }\end{array}$ & Article 2 \\
\hline 9 & $\begin{array}{l}\text { Less than one- } \\
\text { third }(29 \%)\end{array}$ & say & $\begin{array}{l}\text { Biden has made the protests } \\
\text { more dangerous }\end{array}$ & Article 2 \\
\hline 10 & $\begin{array}{c}\text { Among } \\
\text { Republicans, } \\
81 \% \\
\end{array}$ & say & $\begin{array}{c}\text { the Black Lives Matter } \\
\text { movement makes protests } \\
\text { more dangerous }\end{array}$ & Article 2 \\
\hline 11 & $\begin{array}{c}72 \% \text { of } \\
\text { Democrats }\end{array}$ & say & $\begin{array}{l}\text { the same is true about } \\
\text { conservative militias }\end{array}$ & Article 2 \\
\hline 12 & $\begin{array}{l}\text { Almost half, } \\
44 \%\end{array}$ & say & they "strongly" oppose it & Article 3 \\
\hline 13 & $\begin{array}{c}\text { Aaron Jones, } \\
\text { 40, a } \\
\text { Republican } \\
\text { from Katy, } \\
\text { Texas } \\
\end{array}$ & says & "That was a bad call," & Article 3 \\
\hline 14 & $\begin{array}{c}\text { Jane Gillespie, } \\
26, \mathrm{a} \\
\end{array}$ & says & $\begin{array}{l}\text { "That's kind of sad that } \\
\text { force had to be used," }\end{array}$ & Article 3 \\
\hline
\end{tabular}




\begin{tabular}{|c|c|c|c|c|}
\hline No. & Sayer & $\begin{array}{l}\text { Verbal } \\
\text { process }\end{array}$ & Verbiage & Source \\
\hline & $\begin{array}{c}\text { Republican } \\
\text { from Glendale, } \\
\text { Arizona } \\
\end{array}$ & & & \\
\hline 15 & $\begin{array}{l}\text { Thirty-eight } \\
\text { percent of } \\
\text { Americans }\end{array}$ & say & $\begin{array}{l}\text { they trust Trump to } \\
\text { promote justice and equal } \\
\text { treatment for people of all } \\
\text { races }\end{array}$ & Article 3 \\
\hline 16 & $\begin{array}{l}\text { Brittany Baca, } \\
\text { 31, a Democrat } \\
\text { from Oregon } \\
\text { City }\end{array}$ & says & $\begin{array}{l}\text { "I think it speaks volumes } \\
\text { that the (former) presidents } \\
\text { have kind of unified and } \\
\text { that so much of the country } \\
\text { is unified in its feeling," }\end{array}$ & Article 3 \\
\hline 17 & $\begin{array}{c}\text { Baca, the } \\
\text { daughter of a } \\
\text { police officer }\end{array}$ & says & $\begin{array}{l}\text { "It just breaks our hearts to } \\
\text { hear what's going on in the } \\
\text { country," }\end{array}$ & Article 3 \\
\hline 18 & $\begin{array}{l}\text { Three-fourths of } \\
\text { Democrats, } 73 \%\end{array}$ & say & $\begin{array}{l}\text { the protests after Floyd's } \\
\text { death have been mostly } \\
\text { peaceful }\end{array}$ & Article 3 \\
\hline 19 & $\begin{array}{l}54 \% \text { majority of } \\
\text { Republicans }\end{array}$ & say & $\begin{array}{c}\text { they have been mostly } \\
\text { violent }\end{array}$ & Article 3 \\
\hline 20 & $\begin{array}{l}\text { Two-thirds of } \\
\text { Democrats }\end{array}$ & say & $\begin{array}{l}\text { the right to protest is the } \\
\text { most important thing to } \\
\text { ensure, "even if it means } \\
\text { there are some incidents of } \\
\text { violence" }\end{array}$ & Article 3 \\
\hline 21 & $\begin{array}{l}\text { Two-thirds of } \\
\text { Republicans }\end{array}$ & say & $\begin{array}{l}\text { law and order is the most } \\
\text { important thing to ensure, } \\
\text { "even if it means limiting } \\
\text { peaceful protests." }\end{array}$ & Article 3 \\
\hline 22 & $\begin{array}{l}\text { Cliff Young, } \\
\text { president of } \\
\quad \text { Ipsos }\end{array}$ & says & $\begin{array}{l}\text { "Views toward George } \\
\text { Floyd's killing and the } \\
\text { subsequent protests tell a } \\
\text { tale of two Americas," }\end{array}$ & Article 3 \\
\hline 23 & Sixty percent & say & Floyd was murdered & Article 3 \\
\hline 24 & just $2 \%$ & say & $\begin{array}{l}\text { the police officer "did } \\
\text { nothing wrong }\end{array}$ & Article 3 \\
\hline 25 & $\begin{array}{l}\text { Maira Nigam, } \\
62 \text {, a Democrat } \\
\text { from Stamford }\end{array}$ & says & $\begin{array}{l}\text { "So they still have hope. } \\
\text { We'll see if that holds up." }\end{array}$ & Article 3 \\
\hline 26 & $\begin{array}{l}\text { Taurice Bussey, } \\
\text { a } 25 \text {-year-old } \\
\text { University of }\end{array}$ & said & "I would say it's a start," & Article 4 \\
\hline
\end{tabular}




\begin{tabular}{|c|c|c|c|c|}
\hline \multicolumn{5}{|c|}{ Mahitab Mohamed Ahmed } \\
\hline No. & Sayer & $\begin{array}{l}\text { Verbal } \\
\text { process }\end{array}$ & Verbiage & Source \\
\hline & $\begin{array}{c}\text { South Carolina } \\
\text { graduate }\end{array}$ & & & \\
\hline 27 & Nikki Bowdoin & said & "That's just who I am." & Article 4 \\
\hline 28 & $\begin{array}{l}\text { Herold, the } \\
\text { director of the } \\
\text { Crowd } \\
\text { Management } \\
\text { Research } \\
\text { Council }\end{array}$ & said & $\begin{array}{c}\text { "Most demonstrations, } \\
\text { most protests, are peaceful. } \\
\text { Very few ever involve } \\
\text { violence." }\end{array}$ & Article 5 \\
\hline 29 & $\begin{array}{c}\text { David Dulio, } \\
\text { director of the } \\
\text { Center for Civic } \\
\text { Engagement at } \\
\text { Oakland } \\
\text { University }\end{array}$ & said & $\begin{array}{c}\text { "If there was a rock-ribbed } \\
\text { Republican area in } \\
\text { Michigan, it's West } \\
\text { Michigan," }\end{array}$ & Article 5 \\
\hline 30 & $\begin{array}{c}\text { Jackson, of } \\
\text { Ipsos }\end{array}$ & said & $\begin{array}{l}\text { it's too early to tell whether } \\
\text { the protests will lead to a } \\
\text { boost in turnout this fall }\end{array}$ & Article 5 \\
\hline 31 & $\begin{array}{l}\text { Terry Madonna, } \\
\text { director of the } \\
\text { Center for } \\
\text { Politics and } \\
\text { Public Affairs }\end{array}$ & said & $\begin{array}{c}\text { "We're going through a } \\
\text { period of tremendous } \\
\text { change," }\end{array}$ & Article 5 \\
\hline
\end{tabular}

USA Today used 31 verbal processes in 5 articles. However, none of them represent the voice or the demands of the protesters. The sayers of all the verbal processes are American citizens and politicians. In addition, all the above mentioned verbiages are comments and opinions about the protesters and the protests.

Table 6. Material Processes in USA Today

\begin{tabular}{|c|c|c|c|c|c|}
\hline No. & Actor & $\begin{array}{c}\text { Material } \\
\text { process }\end{array}$ & Goal & Circumstance & Source \\
\hline 1 & $\begin{array}{l}\text { George Floyd } \\
\text { protests }\end{array}$ & reach & $\begin{array}{l}\text { even small } \\
\text { cities }\end{array}$ & & Article 4 \\
\hline 2 & 970 protests & had taken place & & $\begin{array}{c}\text { in about } 400 \\
\text { cities }\end{array}$ & Article 5 \\
\hline 3 & protests & were occurring & & on a given day & Article 5 \\
\hline 4 & protests & continue & & & Article 5 \\
\hline 5 & $\begin{array}{l}\text { The protests in } \\
\text { Lincoln and other } \\
\text { parts of the state }\end{array}$ & may reflect & $\begin{array}{c}\text { the growing } \\
\text { diversity }\end{array}$ & & Article 5 \\
\hline 6 & protests & began & & in May & Article 5 \\
\hline
\end{tabular}


USA Today has only 6 material processes in 5 articles. The actors of these 6 processes are the protesters.

\section{Discussion}

Table 7. Results of the Verbal and Material Processes Analysis

\begin{tabular}{|c|c|c|}
\hline Name of the Newspaper & Verbal Processes & Material Processes \\
\hline Al-Ahram Weekly & $1 \wedge$ processes & $1 \uparrow$ processes \\
\hline The Guardian & 26 processes & 19 processes \\
\hline USA Today & 31 processes & 6 processes \\
\hline Total & $\mathbf{7 5}$ verbal processes & $\mathbf{3 7}$ material processes \\
\hline
\end{tabular}

In this analysis, the potential participant roles the researcher focuses on are sayer, who is the doer of process, and verbiage. The whole verbal processes in the selected articles mainly serve as the description of the comments and points of view of some politicians. The reporter borrows those quotations to express his ideology. Thus, the choice of verbs in the verbal process can also indicate the writers' attitude. The most common verb in the previous examples is "say" which reflects what politicians think about the protests and the protesters. Using the verbal processes, the writers show how the protesters are viewed from different perspectives.

Material processes are those of 'doing' whereby a person or thing does something which may, "in turn be performed by another person or thing" (Halliday, 1994: 110). In this part of the analysis, the researcher focuses on all the protesters' material processes. Material processes show that the protesters are engaged as actors who are involved and responsible for their own doings. For example, the actors of the material processes in the three newspapers are peaceful protests, demonstrators, sizable protests, George Floyd protests, and US protests. Therefore, the protesters are the actors of all the previous material processes. The verbs in these material processes show how the protesters are effective and active.

Finally, it is obvious that the number of the verbal processes in the three newspapers outweighs the number of the material processes. In Table 7, it is clear that the three newspapers focus on the verbal processes rather than focusing on the material processes. In addition, USA Today newspaper focuses on the verbal processes more than the other two newspapers. This reflects its ideology towards focusing on the point of views of others rather than focusing on the actions of the protesters.

The results reflect that the three selected newspapers focus on the importance of the transitivity choices that have been made to represent the protests. Verbal processes interpret saying. Thus, the analysis highlights the consistency of mentioning and stating the opinions of people rather than the opinions of the protesters themselves. Moreover, the material processes in the three newspapers show the doers, who are 


\section{Mahitab Mohamed Ahmed}

the protesters, as strong and active characters. However, they are less than the verbal processes. Finally, the analysis shows the degree to which transitivity patterns can contribute to the reader's interpretation of the participants and the events of a text. Therefore, transitivity can create unequal relations of power, revealing something about the writer's ideology.

\section{Conclusion}

There are various verbal and material processes emerged from the analysis. The total number of verbal processes in the three newspapers is 75 verbal processes, while the total number of the material processes is 37 material processes. Thus, the number of the verbal processes outweighs the number of the material processes. Therefore, results of the study indicate that verbal processes dominate the three selected newspapers. This shows that the main aim of the three newspapers is to mention the opinions and the comments of citizens and politicians about the events. The transitivity analysis revealed the underlying ideologies of each newspaper as they represent the protesters as active and responsible for their actions in the material processes. However, they pay more attention to the verbal processes. In Al Ahram Weekly, the focus of the verbal processes is the politicians' opinions which reflect the ideology of persuading the readers with such opinions. Al Ahram Weekly did not mention any of the protesters' chants during the protests. Similarly, The Guardian and USA Today focus on the ideology of convincing the readers with the different point of views about the protests rather than reflecting the real demands of the protests. 


\section{References}

Fairclough, N. (1992). Discourse and text: Linguistic and intertextual analysis within discourse analysis. Discourse \& society, 3(2), 193-217.

Fairclough, N. (2013). Critical Discourse Analysis: The Critical Study of Language. (2nd ed.) New York: Routledge.

Halliday, M. (1994). An Introduction to Functional Grammar (2nd ed.). China: Edward Arnold (publishers) Ltd.

Mayr, A. (2008). Language and Power: An Introduction to Institutional

Discourse. New York: Continuum.

Sunderlin, W. D. (2003). Ideology, social theory, and the environment.

Rowman \& Littlefield.

Thornborrow, J. (1999). Language and the media. In Thomas, L. and Wareing,

S. (Eds). Language, society and power. London: Routledge.

Top national newspapers ranked by reach UK 2014 | statistic. (n.d.). Retrieved

September 8, 2014 from

http://www.statista.com/statistics/246077/reach-of-selected-nationalnewspapers-in-the-uk/

Van Dijk, T. A. (1998). Ideology: A multidisciplinary approach. London:Sage.

Van Dijk, T. A. (2000). New (s) racism: A discourse analytical approach.

Ethnic minorities and the media, 37, 33-49.

Wodak, R., \& Reisigl, M. (2001). The Semiotics of Racism. Approaches in Critical Discourse Analysis. Passagen Verlag.

2014 Top Media Outlets: Newspapers, Blogs, Consumer Magaines Social Networks Websites, and Broadcast Media. (n.d.). Retrived September8, 2014, from http://www.burrellesluce.com/resources/top_media_outlets 